\title{
Chinese academics share human rights prize
}

London. Two eminent Chinese intellectuals, who last week were involved in drafting and circulating a petition to the government calling for an amnesty for those involved in the 1989 pro-democracy demonstrations, are to share a human rights award conferred by the New York Academy of Sciences.

In an announcement due to be made today (25 May), Xu Liangying, a 75-year-old retired professor who has edited and translated the collected works of Einstein, is expected to receive this year's Heinz Pagels Award for the advancement of the human rights of scientists.

He will share the prize with Ding Zilin, a professor of philosophy at the People's University in Beijing. Her 17-year-old son died on the first night of the government crackdown on pro-democracy demonstrators in Tiananmen Square in 1989.

Past recipients of the award, to be presented later this year, include the late Andrei Sakharov, the former Soviet dissident physicist, and Fang Lizhi, a prominent Chinese pro-democracy activist who is now professor of physics at the University of Arizona.

$\mathrm{Xu}$ Chenggang, Xu Liangying's son who is an economics lecturer at the London School of Economics, says the award "is a great honour for my father". He adds that "it will mean a lot, especially at this time."

Meanwhile, government authorities in China reacted with predictable hostility to the petition drafted on 15 May by Liangying and signed by 45 intellectuals, including Wang Ganchang, the 88-year-old physicist who played a leading role in China's fission programme.

The signatories also include 15 members of the Chinese Academy of Sciences and eight women professors. The letter was delivered to both President Jiang Zemin and Qiao Shi, chairman of the National People's Congress, China's parliament.

Five signatories have already been arrested, including Wang Dan, a prominent student leader, and Huang Xiang, a leading poet. The rest are said to be under police surveillance.

Communist Party officials have visited the houses of at least two of the scientists, urging them to withdraw their names from the letter. Also under arrest is Liu Xiabo, a literary critic who is responsible for circulating a separate letter to the government.

The American Physical Society, which recently established official contact with its Chinese counterpart, has written to the Chinese President, Jiang Zemin, expressing concern over reports that Wang Ganchang is one of the scientists being harassed.

According to authoritative sources in Beijing, Communist Party officials are said to have questioned the octogenarian for three hours. They then refused to leave his residence, or allow him to sleep until he signed a statement saying his signature on the petition was a mistake.

The sources said Ganchang "steadfastly refused to sign". But unconfirmed reports suggest he may have been persuaded to put his name to another statement saying he was not aware that the petition would be published overseas.

$\mathrm{Xu}$ Liangying said in a telephone interview from his home in Beijing that his mail is being intercepted, although there are as yet "no restrictions" on his movements. "I can come and go wherever and whenever I

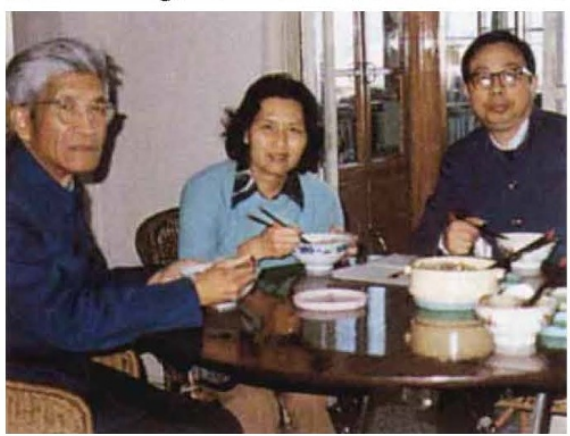

Xu Liangying (left) meets with former awardrecipient, physicist Fang Lizhi (right) and his wife Li Shuxian (centre).

want," he said through an interpreter, adding that three police cars stationed outside his house "have not stopped me from anything".

Nevertheless, the telephone conversation was cut off at least half-a-dozen times, and Liangying emphasized that contact with foreign journalists was being made progressively more difficult.

The letter's signatories are the highestranking group to have defied a government ban on organized protest since 1989 . They use as the letter's theme a United Nations resolution proclaiming 1995 as the UN's Year of Tolerance.

The petition, specifically, urges the authorities to "treat all views such as ideology, political thought and religious belief with a spirit of tolerance and never again regard individuals of independent thought

\section{Amazon scientists seek funds for Internet link}

London. Scientists working in the central Brazilian Amazon have issued a plea for funds to save their solitary Internet connection, which is due to be severed by Embratel, the Brazilian telephone monolith on 12 June.

The satellite link is to be cut as the Rede Nacional de Pesquisa - the Brazilian Internet - says it is no longer able to continue paying the $\$ 15,000$ monthly connection bill.

The link is used extensively by scientists working for the Instituto Nacional de and views as 'hostile elements' and submit them to repressive attacks, surveillance, house arrest, even detention". It also calls for a re-evaluation of "the 4 June 1989 incident, seeking truth from fact and release those people who remain in jail".

Despite the letter's link with the UN Year of Tolerance, observers believe its timing may have been influenced by a number of additional factors. Two recent government announcements are likely to have been in the signatories' minds, says Xiao Qiang, a spokesman for Human Rights for China, based in New York.

One was a decision to mount an official crackdown on corruption in China's public sector after the mayor of Beijing, Chen Xitong, resigned four weeks ago, following the suicides of two of his deputies who had been implicated in a corruption scandal. The second was a government statement promising to treble the country's science budget by the year 2000 (see Nature 375, 175; 1995).

"The scientists who signed the petition say it is meaningless to have campaigns against corruption or promises to increase the science budget, when there is no human rights or democracy," says Qiang, an astrophysicist by training who now works as a human rights activist.

"When the government makes such pronouncements, it usually means the situation is getting dire," he says. "Scientists welcome the money, but they find it difficult to be motivated without guarantees for their rights," adds Xu Chenggang.

Another observer, however, believes that the petition's timing may also be related to the disarray over the succession to the ailing elder statesman Deng Xiaoping. "My guess is that these scientists wanted to test the water," says Steve Tsang, a fellow at the Centre for Modern Chinese Studies at St Antony's College, Oxford.

"A not-too-brutal response might be an indication that the government is too divided; meaning this is a good time to push for a reversal of the verdicts handed down on those who took part in the 1989 demonstrations."

Ehsan Masood

Pesquisas da Amazonia (the National Institute for Amazonian Research). But the state of Amazonas contains less than two per cent of the country's population, making the Internet link the country's most expensive.

A source at the Brazilian Internet said another reason for cutting the link could be the impending commercialization of Internet access in Brazil. "The Rede Nacional de Pesquisa is at this moment in the middle of heated negotiations with Embratel," he said. 